\title{
OVERVIEW OF BLOOD STOCKS AND DEMAND DURING THE COVID-19 PANDEMIC IN BLOOD DONATION UNIT PMI SLEMAN YOGYAKARTA
}

\author{
Novita Widy Astuti ${ }^{1}$, Nur'Aini Purnamaningsih ${ }^{1 *}$, Tri Sunarsih ${ }^{1}$ \\ ${ }^{1}$ Fakultas Kesehatan, Universitas Jenderal Achmad Yani Yogyakarta, Yogyakarta, Indonesia
}

*Correspondence email: nurainipurnamaningsih21@gmail.com

\begin{abstract}
The objectives of this study were to describe the stock and demand for blood during the Covid-19 pandemic at the Blood Donation Unit PMI Sleman Regency in 2019-2020, as well as efforts to meet the availability of blood stocks. This research was a quantitative descriptive study with a retrospective approach. The results showed that due to the Covid-19 pandemic, blood stocks at Blood Donation Unit PMI Sleman Regency increased from 11.500 bags in 2019 to 12.303 bags in 2020. Furthermore, the demand also increased from 11.487 bags in 2019 to 12.515 bags in 2020. During the Covid-19 pandemic in 2020, 212 requests for blood $(1,69 \%)$ could not be fulfilled due to a lack of blood supply caused by the reduced presence of donors. Efforts to fulfill blood stocks were carried out by improving services and supporting facilities.
\end{abstract}

Keywords: Blood Donation; Blood Stocks; Blood Demand; Covid-19

\section{INTRODUCTION}

Blood transfusion service is a health service effort that includes planning, mobilizing, and preserving blood donors, supplying blood, distributing blood, and giving blood to patients for medical purposes, healing of illnesses, and restoring health. ${ }^{1}$ Blood donation is the process of taking blood from a person voluntarily to be stored in a blood bank for blood transfusions. ${ }^{2}$ The blood transferred can be in the form of whole blood and blood components. Usually, this is often done among teenagers to adults, the need for donors' wishes starting from their late teens to form a habit, and social spirit because blood is obtained from blood donations from voluntary blood donors and substitute blood donors. A voluntary blood donor is someone who donates blood voluntarily to benefit a community in need without knowing for whom. ${ }^{3}$ In connection with that, awareness from all levels of society is needed to play a direct role. Indonesia should have bloodstock of 4.5 million to 4.8 million blood bags per year.
In comparison, Blood Donation Units can only meet around 2 million blood bags, 64 percent of which are processed into blood components. As many as 3 million blood components can meet 70 percent of the needs of the blood of Indonesian residents in 520 Cities/Regencies. The thing that causes a lack of blood supply in Indonesia is the lack of public awareness about the importance of donating blood. To increase the blood supply capacity set by WHO, PMI seeks to improve the Blood Donation Units' quality and service, which are scattered in around 200 PMI Cities/Regencies throughout Indonesia. PMI has also built Blood Donation Units in 6 Malls and 2 Universities, one of PMI's anticipations to bring voluntary blood donation services closer to the community and fulfill the need for national blood bags. One in four people in the world may need blood transfusions during their lifetime, but only $37 \%$ of the population is eligible to donate blood, and only under $10 \%$ are willing to donate blood regularly. The annual need for blood in an area is $2 \%$ of the area's population. Based on Central PMI data in 2013, we still lack 600,000 liters of bloodstock. Blood donation is helpful for a 
palliative aspect that focuses on patients with serious or life-threatening illnesses. ${ }^{4}$

World Health Organization (WHO) recently declared the 2019 coronavirus disease (Covid-19) a public health emergency of international concern. As of February 25, 2020, a total of 81,109 laboratory-confirmed cases have been documented globally. ${ }^{5}$ The outbreak of a new virus, namely a new type of coronavirus (SARS-CoV-2), was initially known to have originated in Wuhan, China. ${ }^{6}$ Staying at home and practicing Physical Distancing is no exception in Indonesia. This condition creates an excessive sense of anxiety for the community and dramatically affects the amount of stock and demand for blood in all regions, including in the Sleman Regency. At this time, people who usually routinely donate blood every two months have become less, resulting in the depletion of blood stocks at PMI.

SARS-CoV-2 is transmitted mainly through respiratory droplets and close contact. Although the possibility of transmission of SARS-CoV-2 through blood and blood products is still unclear, the positivity of SARS-CoV-2 in the blood during the incubation period is still a potentially important threat to blood safety. ${ }^{7}$ The lack of knowledge about Covid-19 transmission encourages actions to convince the public about the safety of donating blood. To date, no cases of SARS-CoV-2 transmission have been reported by any blood product, but transfusion transmission cannot be wholly excluded. Therefore, proactive action, in addition to donor eligibility and suspension policies based on local issues, can be considered to ensure safe transfusions. ${ }^{8}$

Blood needs during this pandemic must still be met, forcing PMI to find new, appropriate solutions to reduce anxiety and increase public interest in donating blood might be an alternative. Each Blood Donation Unit has the responsibility to meet the availability of blood in its working area or network. During this pandemic, it is necessary to make efficient efforts in donor recruitment activities which include socialization efforts and voluntary blood donor campaigns, donor mobilization, and donor preservation carried out by each blood service unit, including Blood Donation Unit PMI Sleman Regency to be able to meet the availability of blood. Therefore, the objectives of this study were to describe the stock and demand for blood during the Covid-19 pandemic at Blood Donation Unit PMI Sleman Yogyakarta in 2019-2020.

\section{MATERIALS AND METHODS}

This research was a quantitative descriptive study with a retrospective approach. The data was collected at Blood Donation Unit PMI Sleman Yogyakarta in March-April 2021 with a total sampling technique of 23,803 blood bags and 24,002 blood requests. The variables in this study were the number of stock and blood demand variables in 2019-2020. The data collection tools used were checklist sheets/donor attendance records in the building/mobile blood donor (mobile unit) and blood inventory records encapsulated in the Blood Donation Management System (SIMDONDAR). The data that has been collected was then edited and cleaned. The data analysis used was univariate analysis using frequency distribution and percentage.

\section{RESULTS AND DISCUSSION Total of Blood Stocks in 2019}

Table 1 showed that the highest number of blood stocks obtained in 2019 was in March, 1,295 bags (11.26\%) with 326 bags obtained from in-building donor activities and 969 bags obtained from Mobile Unit (MU) activities. While the lowest number of blood stocks obtained in 2019 was in February, namely 620 bag units (5.39\%) with details of 342 bag units obtained from inbuilding donor activities and as many as 278 bag units obtained from MU. 
Table 1. Total of Blood Stocks in 2019

\begin{tabular}{lcccc}
\hline \multirow{2}{*}{ 2019 year } & \multicolumn{2}{c}{ Blood stock/units } & \multicolumn{2}{c}{ Total } \\
\cline { 2 - 5 } & $\begin{array}{c}\text { In the } \\
\text { building }\end{array}$ & $\begin{array}{c}\text { Mobile } \\
\text { Unit } \\
\text { (MU) }\end{array}$ & N & $\mathbf{( \% )}$ \\
\hline January & 479 & 293 & 772 & 6.71 \\
February & 342 & 278 & 620 & 5.39 \\
March & 326 & 969 & 1,295 & 11.26 \\
April & 368 & 710 & 1,078 & 9.37 \\
May & 256 & 656 & 912 & 7.93 \\
June & 398 & 284 & 682 & 5.93 \\
July & 258 & 506 & 764 & 6.64 \\
August & 241 & 804 & 1.045 & 9.08 \\
September & 272 & 844 & 1,116 & 9.70 \\
October & 243 & 859 & 1,102 & 9,58 \\
November & 295 & 768 & 1,063 & 9.24 \\
December & 379 & 672 & 1,051 & 9,13 \\
\hline Total & 3.857 & 7,643 & 11,500 & 100 \\
\hline
\end{tabular}

\section{Total of Blood Stock in $\mathbf{2 0 2 0}$}

Table 2 shows that the highest number of blood stocks obtained in 2020 was in June, 1,253 bags (10.18\%), with 479 bags obtained from donor activities in the building and 774 bags obtained from MU activities. While the minimum amount of bloodstock obtained in 2020 was in March, namely 867 bags (7.04\%) with details of 340 bags obtained from inbuilding donor activities and 527 bags obtained from MU.

Table 2. Total of Blood Stock in 2020

\begin{tabular}{lcccc}
\hline & \multicolumn{3}{c}{ Bloodstock / units } & \multicolumn{2}{c}{ Total } \\
\cline { 2 - 5 } 2020 year & $\begin{array}{c}\text { In } \\
\text { Building }\end{array}$ & $\begin{array}{c}\text { Mobile } \\
\text { Unit } \\
\text { (MU) }\end{array}$ & N & $(\%)$ \\
\hline January & 448 & 505 & 953 & 7.74 \\
February & 257 & 778 & 1.035 & 8.41 \\
March & 340 & 527 & 867 & 7.04 \\
April & 324 & 841 & 1,165 & 9.46 \\
May & 352 & 556 & 908 & 7.38 \\
June & 479 & 774 & 1.253 & 10.18 \\
July & 548 & 344 & 892 & 7.25 \\
August & 598 & 584 & 1,182 & 9.60 \\
September & 561 & 411 & 972 & 7.90 \\
October & 570 & 452 & 1,022 & 8.30 \\
November & 417 & 676 & 1.093 & 8.88 \\
December & 509 & 452 & 961 & 7.81 \\
\hline Total & 5,403 & 6,900 & 12.303 & 100 \\
\hline
\end{tabular}

Based on Table 1 and Table 2, there was an increase in the amount of blood stock obtained from blood donations in the building with a value of 1,546 units of blood (40.08\%) during the Covid-19 pandemic in 2019-2020. In contrast, there was a decrease in the number of blood stocks obtained from Mobile Unit (MU) activities by 743 units of blood (9.72\%) during the Covid-19 pandemic in 2020 compared to 2019 before the Covid-19 pandemic. In 2020, there was an increase of $6.98 \%$ in the total bloodstock obtained compared to 2019.

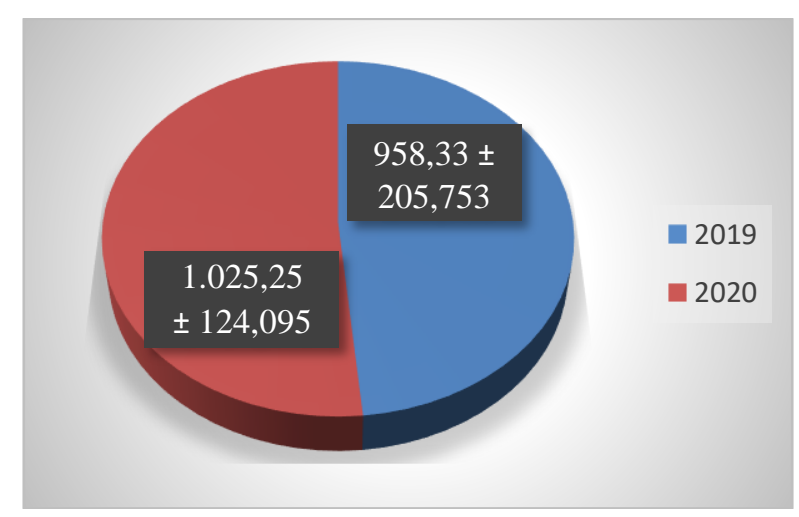

Figure 1. The mean \pm Standard Deviation of Total Blood Stock in 2019-2020 Before and During the Covid-19 Pandemic

This is likely due to the high level of concern and fear of the community gathering in public places such as sub-district and subdistrict offices used as targets for donor recruitment during the Covid-19 pandemic.

Previous research conducted by Djuardi, since of the pandemic people has been exposed to Covid-19 while giving blood. However, to increase the blood supply, the Blood Donation Unit has persuaded people to keep donating blood during the pandemic, as the Blood Donation Unit has implemented protocols consistent with the WHO in all Blood Donation Units in Indonesia. Furthermore, at present, there has been no evidence of Covid-19 by blood transmission, so it is hoped that people will not have to worry about getting exposed to the virus while giving blood. ${ }^{9}$

Previous research conducted by Loua $e t$ al about "The impact of the Covid-19 pandemic on blood supply and demand in the WHO African Region" report that Covid-19 pandemic has led to an overall reduction of 
blood transfusion activities, in particular, blood donations, blood demands, and use in health facilities. However, the experience and measures implemented by countries to overcome the reduced activities and gain the confidence of donors in safe blood donation yielded results. The experiences and measures should find an appreciated place in preparedness plans for future similar shocks to the blood transfusion system. ${ }^{10}$

Previous research conducted at King Abdullah Hospital, Bisha, Saudi Arabia, using a sample of the amount of stock and demand for blood during the Covid-19 pandemic decreased the bloodstock obtained, followed by a decrease in the amount of blood demand. ${ }^{11}$ The blood supply during the pandemic period can still be controlled without causing a gap between the amount of stock and the significant demand for blood and can meet all the current blood needs. Whereas at the Blood Donation Unit PMI Sleman Regency, it was still unable to meet the incoming blood needs during the Covid19 pandemic in 2020 because even though there was an increase in the number of blood stocks obtained.

\section{Total of Blood Demands in 2019}

Table 3. Blood Demand of 2019

\begin{tabular}{lllll}
\hline \multirow{2}{*}{ 2019 year } & \multicolumn{3}{l}{ Demand/units of blood } & Total \\
\cline { 2 - 5 } & $\begin{array}{l}\text { Hospital } \\
\text { Blood } \\
\text { Bank } \\
\text { Dropping }\end{array}$ & $\begin{array}{c}\text { Patient } \\
\text { Transfusion }\end{array}$ & & (\%) \\
\hline January & 617 & 308 & 925 & \\
February & 397 & 230 & 627 & 5.45 \\
March & 726 & 335 & 1.061 & 9.23 \\
April & 625 & 355 & 980 & 8.53 \\
May & 724 & 320 & 1.044 & 9.08 \\
June & 398 & 272 & 670 & 5.83 \\
July & 624 & 282 & 906 & 7.88 \\
August & 624 & 335 & 959 & 8.34 \\
September & 721 & 372 & 1.093 & 9.51 \\
October & 750 & 353 & 1,103 & 9.60 \\
November & 657 & 411 & 1.068 & 9.29 \\
December & 657 & 394 & 1,051 & 9.14 \\
\hline Total & 7,520 & 3,967 & 11,487 & 100 \\
\hline
\end{tabular}

Table 3 shows that the number of requests for blood that entered the Blood Donation Unit PMI in the Sleman Regency in 2019 occurred the most in October, namely 1,103 requests $(9.60 \%)$ with details as many as 750 requests for dropping to Hospital Blood Bank and 353 requests for patient transfusions. Meanwhile, the least number of incoming requests occurred in February, namely 627 requests $(5.45 \%)$ with details as many as 397 requests for dropping to Hospital Blood Bank and 230 requests for patient transfusions.

Table 4. Blood Demand of 2020

\begin{tabular}{lcccc}
\hline & \multicolumn{2}{c}{ Demand / units of blood } & \multicolumn{2}{c}{ Total } \\
\cline { 2 - 5 } 2020 year & $\begin{array}{c}\text { Hospital } \\
\text { Blood } \\
\text { Bank } \\
\text { Droping }\end{array}$ & $\begin{array}{c}\text { Patient } \\
\text { Transfusion }\end{array}$ & & \\
\hline January & 489 & 440 & 929 & 7.42 \\
February & 536 & 386 & 922 & 7.36 \\
March & 369 & 527 & 896 & 7.15 \\
April & 726 & 429 & 1,155 & 9.22 \\
May & 477 & 378 & 855 & 6.83 \\
June & 740 & 521 & 1.261 & 10.07 \\
July & 378 & 487 & 865 & 6.91 \\
August & 642 & 521 & 1,163 & 9.29 \\
September & 672 & 455 & 1.127 & 9.01 \\
October & 508 & 506 & 1.014 & 8.10 \\
November & 587 & 460 & 1,047 & 8.36 \\
December & 765 & 516 & 1,281 & 10.23 \\
\hline Total & 6,889 & 5.626 & 12,515 & 100 \\
\hline
\end{tabular}

\section{Total of Blood Demand in 2020}

Table 4 shows that the number of requests for blood that entered the PMI Blood Donation Unit in the Sleman Regency in 2020 occurred the most in December, namely 1,281 requests $(10.23 \%)$ with details as many as 765 requests for dropping to Hospital Blood Bank and 516 requests for patient transfusions. Meanwhile, the least number of incoming requests occurred in May, namely 855 requests $(6.83 \%)$ with details as many as 477 requests for dropping to Hospital Blood Bank and 378 requests for patient transfusions.

Based on Table 3 and Table 4, there was a decrease in the number of requests for Hospital Blood Bank drop by 631 requests (8.3\%) during the Covid-19 pandemic in 2020 compared to 2019 before the Covid-19 
pandemic. At the same time, there was an increase in the number of requests for patient transfusions of 1,659 requests $(41.82 \%)$. It can be seen that in 2020 there was a total increase in the demand for incoming blood by $8.95 \%$ compared to 2019 . The mean \pm Standard Deviation of blood demand in 2019 before the Covid-19 pandemic was 957.25 \pm 158.051 demand per month while the main \pm Standard Deviation of blood demand in 2020 during the Covid-19 pandemic is 1,042.92 \pm 152.

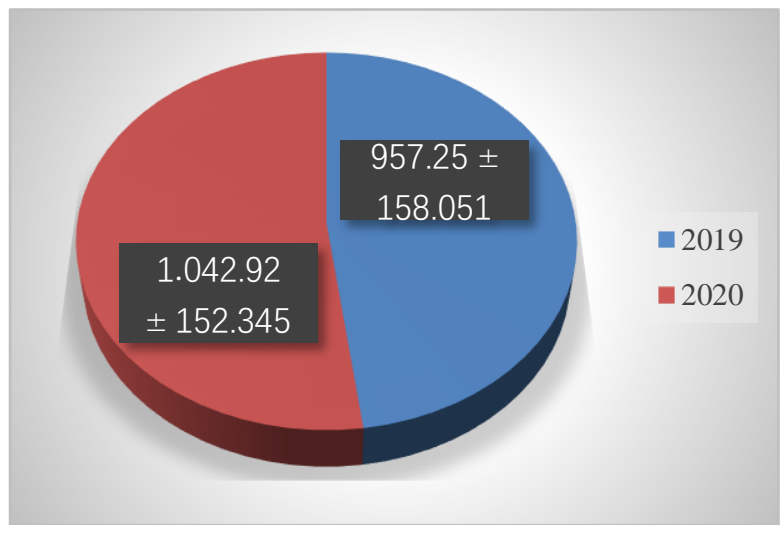

Figure 2. The Main \pm Standard Deviation of Blood Demand for 2019-2020 Before and During the Covid-19 Pandemic

This condition may be due to the increasing number of patients requiring blood transfusions during the pandemic, while the budget for the bloodstock provided at Hospital Blood Bank is insufficient. Following previous research, during Covid19 , the number of routine operations decreased, the use of blood for inpatients continued to experience a slow downward trend. ${ }^{12}$ So, it is directly proportional to the plan or budget for the provision of bloodstock in Hospital Blood Bank, which is reduced than usual before the Covid-19 pandemic.

This research is in accordance with previous research by Wang ${ }^{8}$, the large amount of bloodstock is affected by the Covid-19 pandemic. On the contrary, the large number of requests for blood that entered during the Covid-19 pandemic remain unchanged. ${ }^{8}$ The proportion of the reduction in the number of blood donations at the regional and country levels was also reported by other countries such as Saudi Arabia, Canada, USA, Malaysia, and Zhejiang province in China. In the countries with reduced blood donations, lockdown orders, donor anxiety, and fear of Covid-19 infection during blood donation, which often stems from popular misconceptions and misinformation, have hindered blood donors from accessing blood transfusion services. Unfortunately, it was not possible to correlate the blood collection and usage to the time period where the countries enforced the social distancing measures and when infections started rising due to the decline of the Covid-19 cases in the countries of the region. ${ }^{10}$ Blood Donation Unit PMI Sleman Regency is facing challenges in maintaining bloodstock to meet the demand for blood every month. Many actions must be taken to overcome this challenge. It should be emphasized that not only has the bloodstock increased during the Covid-19 pandemic, but the demand for blood needs from year to year always increases. So that more effective efforts are needed to meet all incoming blood needs, especially in the challenges of the Covid-19 pandemic.

\section{Efforts to Fulfill Blood Stock During the Covid-19 Pandemic}

Bloodstock at Blood Donation Unit PMI Sleman Regency was affected by the Covid-19 pandemic. It was recorded that since March 2020, there has been a decrease in bloodstock by $16.23 \%$ from February before the Covid-19 pandemic began in Indonesia, especially in Sleman Regency. The decrease in bloodstock caused by the decrease in agencies allowed to anticipate crowds and forced to cancel blood donation activities routinely carried out at that agency. In addition, the closure of the campuses has also reduced the number of blood donors from students in Yogyakarta, especially Sleman. Therefore, the Blood Donation Unit PMI Sleman Regency has started to make various new efforts to maintain the availability of blood stocks during the Covid-19 pandemic. The efforts made are: 
a. A proactive service with Mobile Unit (MU) activities between sub-districts in Sleman Regency is routine every two months.

b. Socialization and education about Covid-19 pandemic using pamphlets distributed in certain areas and by utilizing social media.

c. Broadcast method via Short Message Service (SMS) and Whatsapp messenger to call back and preserve donors.

d. An virtual campaign through the Zoom application media for groups of community organizations engaged in humanitarian care activities.

e. Provision of lucky draws or door prizes in the month of Ramadan and the end of the year to attract donors.

f. Donor massage chairs were held to add comfort and motivation to do blood donations at Blood Donation Unit PMI Sleman Regency.

g. An Independent Blood Donation Platform (AMDD) machine is provided to check the duration of the last blood donation.

Another way to prevent Covid-19 is by educating donors about the importance delay blood donation if they feel less healthy or showing symptoms of Covid-19. Then the postponement of donors also needs to be done for donors who are at risk, such as people who have just fully recovered from Covid-19, people under surveillance (ODP), patients in supervision (PDP), and new people travel to Covid-19 red zone areas. These people should not donate blood for at least 28 days. In addition, if the donor has respiratory tract disease within 28 days after donating blood, you must immediately submit it to the donor center. ${ }^{9}$

The various efforts that Blood Donation Unit PMI Sleman Regency has made since March 2020 at the beginning of the Covid-19 pandemic have shown promising results in early to mid-2020 to meet blood needs every month. However, in September and December, at the end of the year, there was a decrease in the amount of incoming bloodstock compared to the previous month, resulting in some unmet demand for blood that month, as shown in Figure 3.

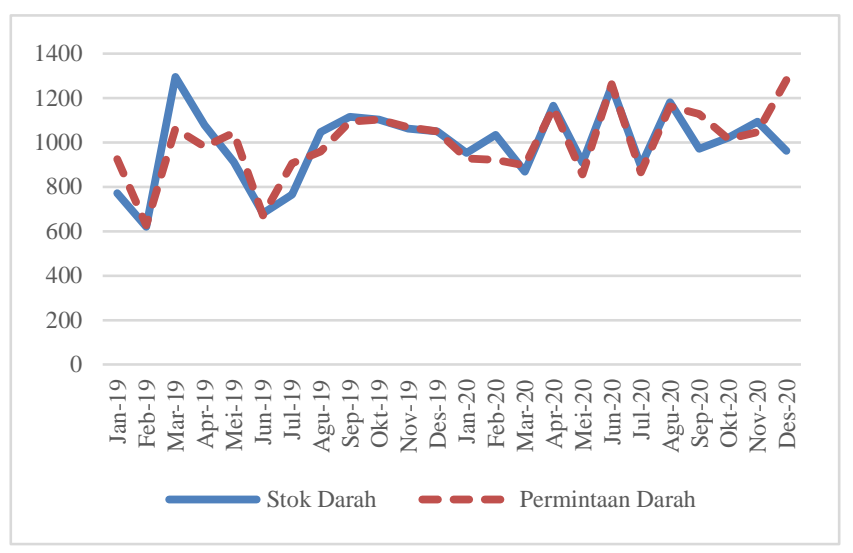

Figure 3. Comparison of Blood Stock and Demand for 2019 and 2020

Figure 3 shows that in comparing the amount of stock and demand for blood in 2020, there was an increase in the amount of stock and demand for incoming blood, which was quite volatile compared to 2019. However, at the end of 2020, there was an increase in blood demand and decreased bloodstock. That way, during the Covid-19 pandemic in 2020, 212 requests for blood $(1.69 \%)$ could not be fulfilled due to a lack of blood supply.

The reduced blood supply occurred because many people were worried about being exposed to the SARS-CoV-2 virus when they donated blood. While in reality, there have been no reports of Covid-19 transmission through blood. ${ }^{12}$ In the case report by Cho et al. ${ }^{5}$, said that there was a patient with aplastic anemia in South Korea who received a platelet transfusion in February 2020. One day after the transfusion was carried out, the donor who gave the patient his platelets was confirmed positive for Covid-19. After that, the patient was immediately tested for Covid-19 using realtime reverse transcription (RT)-PCR and the results were negative. The patient showed no signs of infection and no evidence of pneumonia on a chest CT scan. ${ }^{13}$

Until now, there are no cases of SARSCov-2 transmission due to transfusion of any blood products. Therefore proactive action, as 
well as donor eligibility and local coping policies, can be considered to ensure safe transfusions

\section{CONCLUSION}

This research revealed that the Covid19 pandemic impacts bloodstock and demand at Blood Donation Unit PMI Sleman Regency in 2019-2020. Indirectly, the Covid-19 pandemic increased the number of blood stocks while increasing the amount of incoming blood demand, resulting in unfulfilled blood needs in 2020 during the Covid-19 pandemic. Therefore, efforts to fulfill the number of blood stocks are needed that are more effective and efficient to face challenges during this pandemic. Close monitoring of the amount of stock and demand for blood and the appropriate response is needed to avoid sudden blood shortages, especially for blood components with short shelf life, such as platelets. Furthermore, it is advisable to carry out regular public awareness campaigns about Covid-19, the safety of the blood donation process.

\section{REFERENCES}

1. Kemenkes 2015. Regulation of the minister of health RI number 91 of 2015 concerning blood transfusion service standards. 2015;(36):5,6.

2. Daradjatun. Guidelines for Blood Transfusion Services. Jakarta: Central Blood Transfusion Unit; 2008.

3. Zen AE. Blood Donation Benefits. kabarindonesia.com [Internet]. 2009; Available from: http://kabarindonesia.com/berita.php?pil $=3 \& \mathrm{jd}=$ Manfaat + Donor + Darah $\& \mathrm{dn}=20$ 090813144912

4. Kuncoro. Effects of Blood Donation. Yogyakarta: Graha Ilmu; 2015.

5. Guan W, Ni Z, Hu Y, Liang W, Ou C, He $\mathrm{J}$, et al. Clinical Characteristics of Coronavirus Disease 2019 in China. N Engl J Med. 2020;382(18):1708-20.

6. Yuliana Y. Corona virus diseases (Covid19): Sebuah tinjauan literatur. Wellness Heal Mag. 2020;2(1):187-92.
7. Yuan Z, Chen D, Chen X, Wei Y. Estimation of the number of blood donors during the COVID-19 incubation period across China and analysis of prevention and control measures for blood transfusion transmission. Transfusion. 2020;60(8):1778-84.

8. Wang Y, Han W, Pan L, Wang C, Liu Y, $\mathrm{Hu} \mathrm{W}$, et al. Impact of COVID-19 on blood centres in Zhejiang province China. Vox Sang. 2020;115(6):502-6.

9. Djuardi AMP. Donor Darah Saat Pandemi COVID-19. J Med Hutama [Internet]. 2020;02(01):298-303. Available from: http://jurnalmedikahutama.com

10. Loua A, Kasilo OMJ, Nikiema JB, Sougou AS, Kniazkov S, Annan EA. Impact of the COVID-19 pandemic on blood supply and demand in the WHO African Region. Vox Sang. 2021;1-11.

11. Yahia AIO. Management of blood supply and demand during the COVID-19 pandemic in King Abdullah Hospital, Bisha, Saudi Arabia. Transfus Apher Sci [Internet]. 2020;59(5):102836. Available from:

https://doi.org/10.1016/j.transci.2020.10 2836

12. Pagano MB, Hess JR, Tsang HC, Staley E, Gernsheimer T, Sen N, et al. Prepare to adapt: blood supply and transfusion support during the first 2 weeks of the 2019 novel coronavirus (COVID-19) pandemic affecting Washington State. Transfusion. 2020;60(5):908-11.

13. Jeong H, Wan J, Ki S, Kyung Y, Soo J. Journal of Infection and Public Health COVID-19 transmission and blood transfusion: A case report. 2020;13(November 2019):1678-9. 